\title{
Testing Model with "Check Technique" for Physics Education
}

\author{
Cihat Demir \\ Faculty of Education, Dicle University, Turkey
}

Copyright $(2016$ by authors, all rights reserved. Authors agree that this article remains permanently open access under the terms of the Creative Commons Attribution License 4.0 International License

\begin{abstract}
As the number, date and form of the written tests are structured and teacher-oriented, it is considered that it creates fear and anxiety among the students. It has been found necessary and important to form a testing model which will keep the students away from the test anxiety and allow them to learn only about the lesson. For this study, qualitative and quantitative methods have been preferred. For the quantitative dimension of the study, test anxiety scale has been used before and after application and the difference has been interpreted statistically via SPSS 21.0. For the qualitative dimension of the study, the students' views have been taken by means of 3 informal questions addressed during an interview. Considering the findings of the study, it is understood that the check technique has proved to reduce the test anxiety and the students have got positive views about this technique. The study is recommended to be applied in high schools and it is thought that it will reduce the test anxiety of high school students, and physics lesson will be comprehended better, thus will help the students correlate between physics lesson and real life with a developed skill of scientific processing.
\end{abstract}

Keywords Assessment-evaluation, Physics Education, Test Anxiety

\section{Introduction}

It is necessary to think about an assessment system which will allow the students to get rid of their anxiety [1] and enable them to learn only about the lesson concerning a lesson which is not easily understood and creates test anxiety for lessons, such as physics.

The fact that Einstein, who came up with $\mathrm{E}=\mathrm{mc}^{2}$ formula, was surprised on his own finding and said it was very hard to understand. And quantum physicist Richard Feyman (1985) [2] said that because no one understands the quantum mechanics, this makes the things harder for the teachers of physics. It is known that physics instructors have been conducting studies to make physics more understandable and they have managed to increase the students' success. Again, it is very pleasing that such studies sometimes find place in educational systems. Physics instructors, as the instructors of other branches, find it useful to cover the lessons as student-centered. Although traditional teaching methods are out of date and student-centered teaching methods are applied, testing and evaluation systems are still mainly teacher-oriented. Another factor that increases the students' anxiety for physics lesson is the concept of the exam. Exam is also known as testing.

Testing is the measuring of a certain knowledge and indicating the result of this measurement with numbers or symbols [3]. Testing can also be stated as a method which numerically specifies humans' characters, qualities, objects and events openly according to formulas and rules [4]. Testing and evaluation in education are conducted on persons, and try to measure the activities occurring in persons' minds. This means that the values to be measured are not tangible but intangible. This fact is one of the most important ones that people have been laying emphasis on. Testing tangible things is easy and results are more clear [5].

Evaluation means collecting of every kind of information and achieving a standard judgment via this information [6]

According to Harlen, (1998) [6] the objectives of evaluation are as following;

1. To help learning (level of development, difficulties etc.),

2. To summarize the success according to scheduled times (informing the parents, other teachers and students by keeping records),

3. To select the students (guiding for selection of study field for next grades),

4. To evaluate the teaching activities (adjustments according to the results),

5. To follow the students' performances based on the school, region or country,

6. To help analyzing of new materials and education reforms.

Traditional evaluation includes tests which have been stabilized by those who prepare process instructions, assessment tool and grading; and this is conducted and 
graded (identical) always in the same way to get comparable results for all exam takers by different exam conductors in different sessions [7] Traditional evaluation does not give information about the student's development process [8], [9]. The evaluation conducted with traditional assessment tools tries to assess the student's knowledge for a short timeframe; it does not reflect student's success or failure in detail and does not reveal the student's mental outline [10], [11], [12].

The evaluation which is functionally and structurally different from traditional evaluations, which are gaining more importance day by day, is called alternative evaluation with a general acceptance. According to Pierce and O'Malley (1992) [13], the alternative evaluation is a type of evaluation which shows what students know and what they are capable of doing. Its objective is to reveal the student's progress and inform the teacher. It is neither a standard nor a traditional evaluation.

Alternative evaluation approaches are given below [14];

- The use of skill and knowledge assesses the activities which are connected to each other, completed and adapted to environments.

- It is integrated into education. It can be distinguished from instructed activities which are standardized and only perform target oriented assessments. In other words alternative evaluation means meaningful learning experience.

- It's flexible. It provides opportunity for different presentation types and learning styles that the student will prefer.

- By means of ensuring the students to analyze their own learning style and thoughts, it teaches self-directed thinking and self-scrutinizing.

\section{Objective}

Although traditional teaching methods are out of date and student-centered teaching methods are applied [15], assessment and evaluation systems are still mainly teacher-centered. This study aims to form a student-centered assessment system.

\section{Significance}

Even though alternative assessment and evaluation methods like performance homework, group review, peer review, student self review, concept map, observation form, attitude scale, checklist apart from written and oral tests are used, it is a known fact that the significance of written tests are much more than others in the eyes of the teacher conducting the evaluation. As the number, date and form of the written tests are structured and teacher-centered, it is considered that it creates fear and anxiety among the students. It has been found necessary and important to form an assessment model which will keep the students away from test anxiety and allow them to learn only about the lesson.

\section{Methodology}

The study was conducted with 34 students who were taking summer school classes of General Physics 1 course in Dicle University, Ziya Gökalp Education Faculty in 2014.

For this study, qualitative and quantitative methods have been preferred. For the quantitative dimension of the study, test anxiety scale has been used before and after application and the difference has been interpreted statistically via SPSS 21.0. As the averages of two different cases of the same group will be compared, paired t-test was used. For the qualitative dimension of the study, students were asked about their views through the interviews.

\section{Data Collection Tools}

\section{Test Anxiety Inventory (TAI)}

Turkish adaptation of the test anxiety inventory, whose original version was developed by Spielberger (1980) [16], was prepared by Öner (1990) [17]. There are 20 articles in total in TAI (Test Anxiety Inventory).

TAI is a 4-point Likert type scale and the students have to respond to the four options: (1) Almost Never, (2) Sometimes, (3) Often and (4) Almost Always. The reliability values of alpha coefficient for subscales of original version of Test Anxiety Inventory were: 0.96 for TAI-T, 0.91 for TAI-W, and 0.91 for TAI-E [15].

TAI is a Likert scale type with quadruple grading. High TAI result shows that test anxiety level is high. To test the validity of TAI, 2 professors and one associate professor were asked for their opinions and the validity of the questions was provided. To determine the reliability of TAI, Cronbach alpha internal consistency coefficients were calculated.

The reliability values of alpha coefficient of Test Anxiety Inventory were ranged from .90 and .92 .

\section{Interview form}

Interview, which is a widespread technique of data collection for a study, is a purposeful conversation in which prepared questions are addressed and answers are given [18]. The interview used in this study consists of informal questions. In order to reveal the students' views about the check technique, a question pool with 5 informal questions was formed by making interviews with Science teachers and academicians. The number of the questions was lowered to 3 by collaborating with an educational sciences specialist according to the expression, order and content of these questions. For the validity of the questions, concerning to what extent these questions represent the check technique which is planned to be used by prospective physics teachers in physics education, two associate professors working in Dicle University, Ziya Gökalp Education Faculty and one assistant professor were consulted for their opinions.

For data analysis, Miles and Huberman's (1994) [19] "data reduction", "data presentation" and "data verification" 
approaches were taken as reference. Firstly, the written answers to questions were combined in electronic environment, forming the data for the study. The data was divided into categories by being decoded with content analysis in conceptual and relational level. There was great care for the categories to have integrity, to be objective and distinguishing and to be presented and interpreted clearly [18], [19], [20] retrieved from [21]. Data analysis was performed by researchers separately. Frequency of participation to categories was calculated.

Reliability is reconciliation of intercoders based on the use of more than one coder [22]. To increase the objectivity of the study and to provide reliability for analysis, the fit percentage of the coders was taken into consideration in the coding of the firs and the last question for the reliability of the researchers conducting the coding. Fit percentage was calculated with the formula (the number of all fitting categories) / (the number of all fitting and all non-fitting categories) (Miles and Huberman, 1994). Reliability coefficient was found to be 0.78 for the question "How do you find using check technique in physics lesson?", and 0.75 for the question "What kind of a relation do you think there is between check technique and test anxiety". These facts were found adequate for the coding reliability of the study.

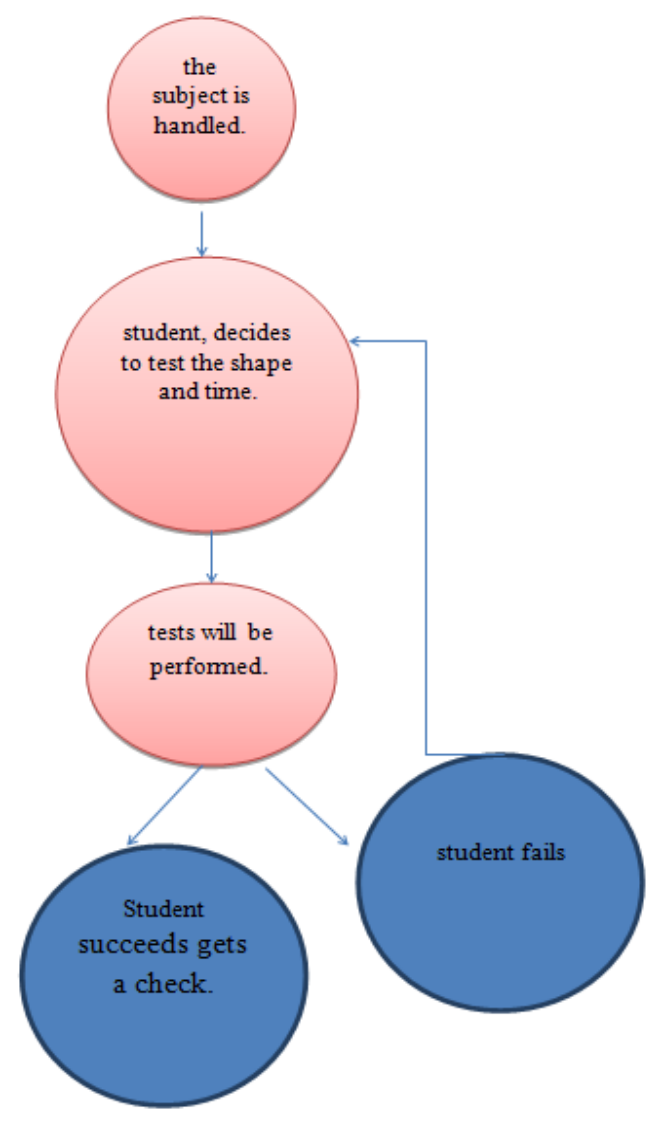

Figure 1. A general overview of Check technique

This study proposes a new kind of assessment technique in which assessment and evaluation will be kept away from test anxiety and fear. Check technique is briefly as follows;
1. Each check's grading is calculated as $100 /$ number of topics

2. Students will be given (tested) as many checks as the number of topics.

3. It will be conducted whenever the student wants.

4. The student will decide on the type of testing (multi choice, fill in the blanks, oral test etc.)

5. If a student gets a passing grade at the test, the student will be given the topic check by the teacher.

6. Even when a student fails a test, he/she has another chance to take when he/she is ready.

7. At the end of the term, a student will specify his/her grade by giving the checks to the teacher.

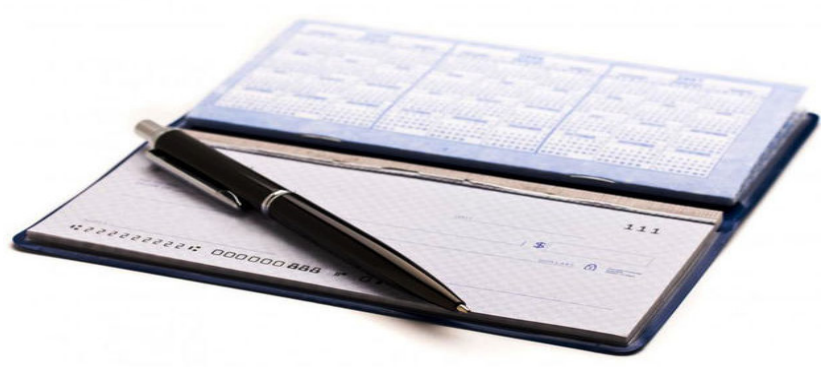

Image 1. Representative Checkbook

\section{Findings}

The findings concerning the test anxiety scale

Table 1. Test anxiety scale pretest - posttest comparison

\begin{tabular}{ccccccc}
\hline Tests & $\mathrm{N}$ & $\mathrm{X}$ & $\mathrm{ss}$ & $\mathrm{t}$ & $\mathrm{p}$ \\
\hline & Pretest & 34 & 2.33 & 0.61 & 5.89 & $0.00^{*}$ \\
& Posttest & 34 & & 2.02 & 0.40 & \\
& & & & & & \\
\hline${ }^{*} \mathrm{p}<.05$ & & & & & &
\end{tabular}

According to Table 1, 34 students have their test anxiety scale pre test grade average as $X_{\text {pretest }}=2.33$ and they have their final test grade average as $X_{\text {Posttest }}=2.02$. There is a statistically significant decrease in the test anxiety of these 34 students whose physics tests were conducted by check technique. This result leads us to the certain thought that there is a significant decrease in the test anxiety of the students who has been tested with check technique.

Students' views on check technique

Table 2. Students' views on check technique

\begin{tabular}{ccc|cc}
\hline \multirow{2}{*}{ Students' views } & \multicolumn{2}{c|}{ Positive } & \multicolumn{2}{|c}{ Negative } \\
\cline { 2 - 5 } & $f$ & $\%$ & $f$ & $\%$ \\
\hline $\begin{array}{c}\text { How did you find using check technique } \\
\text { in physics lessons? }\end{array}$ & 30 & 88 & 4 & 12 \\
\hline
\end{tabular}

$88 \%$ of the students expressed a positive opinion upon asking how they found using check technique in physics lesson.

Some students stated this case as follows: 
"This system is entertaining like a game" Participant 12

"It decreased the stress of preparing for the exams to the lowest point." Participant 5

$12 \%$ of the students expressed a negative opinion upon asking how they found using check technique in physics lesson.

One student stated this negativity as follows: "Somebody who passes the test in one go should not get the same grade as the one who passes it at three trials, this is why I don't find this testing system useful." Participant 30

The opinions were outlined in the implementation of the check technique of the other courses.

Table 3. The opinions were outlined in the implementation of the technical check of the other courses

\begin{tabular}{ccc|cc}
\hline \multirow{2}{*}{ Students' views } & \multicolumn{2}{c|}{ Positive } & \multicolumn{2}{c}{ Negative } \\
\cline { 2 - 5 } & $f$ & $\%$ & $f$ & $\%$ \\
\hline $\begin{array}{c}\text { How do you think it will be to use check } \\
\text { techniques in other courses? }\end{array}$ & 20 & 59 & 14 & 41 \\
\hline
\end{tabular}

Table 3 shows that $59 \%$ of the students expressed positive opinion upon asking how they think it will be to use check technique in other courses. It has been observed that students find it less necessary than physics to use check technique in other courses.

The findings concerning the relationship between the test anxiety and check technique

Table 4. The findings concerning the relationship between the test anxiety and check technique

\begin{tabular}{ccc|cc}
\hline \multirow{2}{*}{ Students' views } & \multicolumn{2}{c|}{$\begin{array}{c}\text { Decreases } \\
\text { pressure }\end{array}$} & \multicolumn{2}{c}{$\begin{array}{c}\text { Does not } \\
\text { effect }\end{array}$} \\
\cline { 2 - 5 } & $f$ & $\%$ & $f$ & $\%$ \\
\hline $\begin{array}{c}\text { What kind of a relation do you think } \\
\text { there is between check technique and test } \\
\text { anxiety? }\end{array}$ & 28 & 82 & 6 & 18 \\
\hline \begin{tabular}{l} 
any \\
\hline
\end{tabular}
\end{tabular}

Table 4 shows that $82 \%$ of the students expressed positive opinions upon asking what kind of a relation they think there is between check technique and test anxiety. $18 \%$ of the students expressed there was no effect between check technique and test anxiety.

\section{Conclusion and Recommendations}

Looking at the findings of this study, it can be clearly observed that there was a statistically meaningful decrease in the test anxiety of 34 students whose tests were conducted with check technique $(p<0.05)$. Considering the results of the interviews conducted with the students at the end of the study, it is clear that the students find using check technique useful in physics lessons, they find using it less useful in other lessons and they got rid of the test anxiety to a large extent.

Previously conducted academic achievement and test anxiety studies support our findings, as well [23], [24], [25]. Study to reduce test anxiety would be supporting the work place [26].

Success rates in science lessons and in physics lesson in particular is remarkably low either with regards to reaching the objectives put for science education or results of the examinations for university and high school acceptance [27].

This study recommends the check technique to be used in high school physics lessons and university departments where physics is taught. It is thought that the test anxiety will decrease and physics lessons will be comprehended better, therefore, there will be more students who can create a relationship between daily life and physics with developed scientific processing skills.

\section{REFERENCES}

[1] Alptekin, S., Demirbaş, M. \& Arıkan., N. (2009). 9. Sınıf öğrencilerinin fizik dersine ilişkin görüşlerinin incelenmesi [Examination of views related physics course of 9th grade students], Sakarya Üniverstesi Eğitim Fakültesi Dergisi [The Journal of SAU Education Faculty], 18, 1-10

[2] Feynman, Richard (1985). QED: The Strange Theory of Light and Matter. Princeton University. Press. ISBN 0-691-08388-6.

[3] Turgut, M. F. (1997). Ĕ̈itimde Ölçme ve Değerlendirme Metotları. Ankara: Yargıcı Matbaası.

[4] Gilbert, S. (1997). Principles Of Educational Psychological Measurement And Evaluation.4th ed. Amazon yayınevi.

[5] Tekin, H. (2000). Eğitimde Ölçme ve Değerlendirme. Ankara: Yarg1 Yayınevi.

[6] Harlen, W. (1998). The Teaching of Science in Primary Schools. (Second Edition). Great Bratin: The Cromwell Press, Trowbridge.

[7] Enger, S. K. and Yager, R. E. (1998). The Iowa Assessment Handbook. ERIC Document Reproduction Service No: Ed 424286.

[8] Cubertson, L. D., Laongo, M.R.(1999). But What's With Letter Grades?. Childhood Education. 75(3). 130-135.

[9] Curtis, M.J., Hunley, S.A., Chesno Grier, J.E. (2002). Relationships Among the Professional Practices and Demographic Characteristics of School Psychologists. School Psychology Review. 31. 30-42.

[10] Manning, M.\& Gary (1995). Portfolios in Reading and Writing. Teaching PreK-8. 25(5). 94-95.

[11] Romberg, T.A. (1993). How One Comes to Know Models and Theories of the Learning of Mathematics. Editör: M. Niss. Investigations into Assessment in Mathematics Education. 97-111. Netherlands: Kluver Academic Publishers.

[12] Shepard, L. (2000). The Role of Assessment in a Learning Culture. Educational Researcher. 20(7). 2-16.

[13] Pierce, L. V. and O'malley, J. M. (1992). Performance and Portfolio Assessment for Language Minority Students. National Clearinghouse for Bilingual Education. Washington: DC.

[14] Korkmaz, H. (2004). Fen ve Teknoloji Eğitiminde Alternatif Degerlendirme Yaklasımları. Ankara: Yeryüzü Yayınevi. 
[15] Demir, C. \& Demir, S. (2014). The Investigation of Physics Teachers' Use of Special Teaching Methods in Their Lessons. International Journal of New Trends in Arts, Sports \& Science Education - 2014, volume 3, issue 1.

[16] Spielberger, C. D. (1980). Test Anxiety Inventory: Preliminary Professional Manual. Palo Alto, CA: Consulting Psychologists Press

[17] Öner, N. (1990). Sinav Kayglsl Envanteri El Kitabı, Y.Ö. Rehberliği Tanıtma ve Rehber Yetirme Vakfi Yay. Yay.No:1 Istanbul.

[18] Kuş, E.(2003). Sosyal Bilimlerde Araştırma Teknikleri Nitel mi, Nicel mi?.Ankara:An1 Yayınc1lı

[19] Miles, B. M., \& Huberman, A. M. (1994). Qualitative data analysis (2nd ed.). London: Sage.

[20] Strauss, A., \& Corbin, J. (1998). Basics of qualitative research: Grounded theory procedures and techniques (2nd ed.). Newbury Park: Sage.

[21] Sahin, İ. (2011). Öğretmen Adaylarının Öğretmen İstihdamı ve Mesleki Geleceklerine İlișkin Görüşleri. Kuram ve Uygulamada Ĕgitim Bilimleri. Educational Sciences: Theory
\& Practice - 11(3).(1167-1184)

[22] Yıldırım, A. ve Şimşek, H. (2000).Sosyal Bilimlerde Nitel Araştırma Yöntemleri (2. bs). Ankara: Seçkin.

[23] Creswell, J. W. (2007). Qualitative inquiry research design: Choosing among five approaches (2nd ed.). London. Sage.

[24] Gündoğdu, M. (1994). "The Relationship Between Helpless Explanatory style, Test Anxiety, and Academic Achievement Among Sixth Grade Basic Education Students". Yayınlanmamış Y. Lisans tezi. Orta Doğu Teknik Üniversitesi, Ankara.

[25] Cengiz, H. F. (1988). "Lise 3. Sınıf Öğrencilerinin ÖSYM 1. Basamak Sınavı Öncesi ve Sonrası Kaygı düzeylerinin Bazı Faktörler Yönünden Karşılaştırılması". Hacettepe Üniversitesi: Yayınlanmamış Y. Lisans tezi, Ankara,

[26] Yıldırım, İ. (2000). Akademik Başarının Yordayıcısı Olarak Yalnızlık, Sinav Kaygisı ve Sosyal Destek. Hacettepe Üniversitesi Eğitim Fakültesi Dergisi 18: 167 - 176.

[27] Eşme, İ. (2004). Çağrılı Bildiri: "Fen Eğitiminde Sorunlar, Fen Bilimleri Merkezi Eğitim Sempozyumları 1", Ortaöğretimde Fen Bilimleri Eğitimi, İstanbul 